\title{
PSYCHOSOCIAL RISKS FOR MENTAL HEALTH DURING A PANDEMIC
}

\author{
Sergey Igumnov \\ Institute of Psychology of the Belarusian State Pedagogical University \\ named after M. Tank, Minsk, Belarus
}

Keywords: anxiety, COVID-19, pandemic, psychoactive substances, quarantine, "self-isolation", stress.

\begin{abstract}
Summary
During the pandemic, many countries go through a period of so-called "self-isolation" or quarantine, during which people are forced for a long time not to see their loved ones, not to visit places of importance to them and experiencing constant anxiety and uncertainty due to changing living conditions. This has had a very negative impact on most people's mental state. Analyzing data from many countries around the world, the World Health Organization (WHO) notes that the fear, loneliness, isolation, stress and anxiety experienced by all people during the COVID-19 pandemic can cause great mental health problems and countries need to be prepared for them. Metaanalysis of studies evaluating the prevalence of mental and behavioral disorders, self-harming behavior, acts of family violence, and problematic substance use in the COVID-19 pandemic show that depression, drug and alcohol addiction, self-harm and suicidal behavior are expected to increase, requiring increased preparedness by mental health services.
\end{abstract}

\section{Introduction}

The World Health Organization (WHO) declared a Coronavirus Pandemic (COVID-19) in March 2020, recognizing it as a global threat to humanity. According to official data [28], cases of COVID-19 have been reported in 216 countries, zones or territories. The global number of confirmed cases is well above seven million, with more than 500000 confirmed deaths.

In addition to the coronavirus pandemic declared by the head of the World Health Organization (WHO), a so-called "bad news pandemic" can be claimed to have spread. Moreover, the fear virus, which spreads around the world following the wave of COVID-19 pandemic, is as dangerous as its biological brother, the consequences of which will be reflected in the mass culture of many peoples.

Purpose of the work is to assess the impact of psychosocial risks associated with the COVID-19 pandemic on the level of mental and behavioral disorders, self-harming behavior, acts of family violence, and problematic psychoactive substance use.

\section{Research material and method}

There is metaanalysis of the international studies evaluating the prevalence of mental and behavioral disorders, selfharming behavior, acts of family violence, and problematic substance use in the COVID-19 pandemic.

Limitations of the study. Due to the fact that official state statistics on the spread of non-medical use of psychoactive substances during the COVID-19 pandemic in the Republic of Belarus and the Russian Federation at the time of preparation of this article (May, 2020) were not available, the assessment of the current drug situation was possible only on the basis of a study of the volume of sales of alcoholic beverages taken from open sources.

Main reasons for the spread of anxiety in society. There are three main reasons for this rapid spread of anxiety in society.

First, the gravity of the biological threat, the severity of the social and economic consequences of quarantine. COVID infection is characterized by high contagion and severe consequences, which, if uncontrolled, lead to numerous victims, as was the case in Ecuador, Italy, Spain, United Kingdom, United States and several other countries [28]. To prevent the spread of the infection, serious anti-epidemic measures are being introduced, with severe economic consequences for the whole state and for individual citizens.

Secondly, modern development of communication means turns any person with a smartphone into a mass media (mass media) with a global audience. The spread of messengers, so- 
cial networks, strips creates a special culture of information delivery - the pursuit of hips. Authors become economically interested in presenting distorted and sometimes knowingly false information. Fear sells well - "fried news" increases the number of views and subscribers. The growth of the audience increases profits from contextual advertising, there are orders for advertising posts. Non-critical perception is reinforced by a special form of presentation: posts on TV channels, comments under the articles are submitted in the form of "experts of last resort", strips are submitted as a reportage from the scene, memes in social networks require a simplified response in the form of likes or dislikes with unconscious approval of the main idea. As a result, a person falls into an information trap, when "everything is already clear", "there is no time to explain, you have to act", "if you disagree, you are against us.

Third, there is the psychological unpreparedness of society for shocks of such magnitude. The last shock, similar in nature and scope, the world experienced exactly one hundred years ago - the Spanish flu epidemic of 1918-1919. In postSoviet countries, more than 20 years have passed since the "dashing nineties". A whole generation grew up in peace and relative prosperity, not knowing the troubles. As a result, the first serious test leads to a mass infantile reaction: a panic buying up "everything in a row", unwillingness to tolerate restrictions, excessive self-confidence that "it will not touch me exactly," the growth of selfishness and atomization of society.

When these three factors come together, they begin to have a negative impact on the mental, physical health and social well-being of the population. At the mental level, this is manifested by an increase in neurotic, anxiety, depressive disorders and an increase in alcohol and substance abuse.

The experienced psychological distress is caused by many different factors. Fears and concerns about our own health and that of our loved ones, as well as fears about the negative social and economic impact of the pandemic, are heightened by the impact of the global media on the crisis, leading to an increased risk of developing anxious and depressive symptoms [8;9].

Prolonged intensive anxiety leads to the formation of such mental disorders as adjustment disorders, generalized anxiety disorder, panic disorder. These include eating disorders (anorexia or bulimia), sleep disorders (insomnia, daytime sleepiness) and sexual dysfunctions. Compulsive search for "signs of infection" leads to the development of somatoform disorders - persistent painful feelings in physically healthy people. Mental exhaustion, the burden of problems, the off-season lead to the formation of depression, from its mild forms, often perceived as a general malaise, to severe, when a person cannot eat, sleep or get out of bed. The most obvious signs of depression are bad moods, lack of joy and loss of strength. If these signs last longer than two weeks, you should seek specialist help from a psychologist, psychotherapist or psychiatrist. Escapism (the desire to escape from problems), idleness and myths about the healing properties of alcohol lead to increased consumption, abuse and provoke drinking. And the abuse starts unnoticed. First it is a can of beer or "a bottle of wine so as not to hurt your head" on weekends, then starts drinking in the evenings "to relieve stress", and there and before drinking (with the desire to "chill" in the morning and a strong, uncontrolled urge to alcohol) is not far away. It has been established and published many times that alcohol consumption reduces the protective properties of the body and complicates the course of coronavirus infection, and the use of alcohol-containing antiseptics "for internal disinfection" and is dangerous for life (unfortunately, such patients, with and without the virus, are already entering the toxicology and intensive care departments).

A special role of anxiety plays in the development of cardiovascular pathology and lies at the heart of the psychosocial risk factor for arterial hypertension [16]. Prolonged strong anxiety, including against the background of positive results of virus testing, perceived as a lethal danger, provokes hypertensive crises and contributes to vascular disasters: insult and myocardial infarction, which may become the real cause of death (even in the times of the Great Plague, a popular rumor was that "half died of fear"). The course of already existing diseases becomes more complicated, ischemic attacks and arrhythmias develop more often.

Restrictive measures and their impact on the daily lives of the general population and their social relations-

hips. Physical distance, telecommuting, school closures and other restrictive measures have had a significant impact on the daily lives of the general population and their social relationships $[23,24,26]$. In particular, quarantine measures expose both adults and children to negative psychological effects, including post-traumatic stress symptoms [22]. Indeed, social isolation and loneliness are largely associated with ill-health and depression $[12,17]$ and are considered a major risk factor for suicidal thoughts and behavior [2].

A serious threat in terms of mental health problems, with the risk of increased suicides in particular, is the increased unemployment [13].

An additional negative factor for many is the spread of the term "involuntary isolation". This term already contains traumatic potential - people, especially young people, do not like to be forced or coerced into something. And we have already seen a number of options for protest behavior in 
foreign news. It would be better to use the definition "protective self-isolation". Psychologically, this is a qualitatively different situation and a message: it is not someone else who orders or forces me to be isolated, but I myself make such a wise decision - it is my self-isolation!

A difficult problem is the temporary transfer of education to remote forms [23]. Many older teachers are sceptic of "distance education". But the world does not stand still, and this form of education is largely the future. All the more so because, with well-established feedback and quality control, graduates of distance education are not inferior to those who attended full-time education. Thus, being in self-protection is a great opportunity for education, retraining and self-development.

The side-effect of absolutely necessary anti-epidemic measures can be the increase of isolation, emotional isolation and distrust to other people. Restrictions on movement, combined with other stressors associated with a pandemic, can exacerbate interpersonal family conflicts. Family conflict, especially conflict between parents and children, is the most common risk factor for adolescent suicide [21].

There are also peculiar, not previously described, violations of social communication that require professional reflection, such as "a false sense of anonymity" under the mask regime. A closed face worsens non-verbal communication, and it becomes difficult to understand what emotions a person experiences. Subtle, weak emotions such as dislike, irritation become difficult to perceive, and strong emotions such as anger are sometimes too late to react. Also the mask on the face (or its absence) in some collectives turns its bearer into "not like the others", "contagious". Suspicion in each person of a "carrier of coronavirus infection" leads to isolation, hostility, reluctance to come into contact. The requirement to maintain a social distance leads to a sense of loneliness and social isolation. The suppression of habitual social gestures, such as the habit of shouting hands, is subconsciously perceived as a manifestation of hostility (remember: "I will not give him a hand!") and reduces friendliness in communication. The accumulated social negativity also has a negative impact on family relations.

The increase in domestic violence against women and children in the conditions of the pandemic. Many researchers in various countries have noted the increase in domestic violence against women and children as a source of serious concern [3;4]. Prohibitive measures have not only forced many women and children to stay home with their abusers, but also made it difficult to access support services. Previous extensive studies have found that domestic violence increases the risk of mental health problems for women [10] and children [7], and it should be noted that intimate partner violence [6] and childhood trauma (i.e. sexual abuse, emotional abuse, and physical neglect) [31] are also associated with attempted suicides resulting from incidents.

Single persons, especially the elderly, are particularly vulnerable in situations of forced isolation. All factors of loneliness diseases, including reduced immunity, will join in. If there are such among your friends or family, call them more often, but do not need to retell terrifying news, and think in advance - what would you and your companion would be interested to talk about? But even if the person you are talking to complains endlessly, listen patiently. By showing kindness and compassion to others, we strengthen our own physical and mental health!

Alcohol and illegal drugs as a serious additional risk factor. A serious additional risk factor for mental and behavioral disorders manifestation is the use of psychoactive substances such as alcohol and illegal drugs. Alcohol and illegal drugs use has been shown to increase as a result of stressful life experiences and economic crises $[5,14,19]$, and there are already statistics showing increased alcohol sales during the current pandemic [1]. Similarly, the global crisis is facilitating access to lethal drugs, a critical risk factor for suicidal behavior [29]. This is due both to the stockpiling of medicines and to the dramatic increase in the sale of firearms reported in some countries, which has the potential to lead to an increase in mass clashes with firearms.

Assessment of the situation with the prevalence of problematic psychoactive substance use in the context of the COVID-19 pandemic. A study of clinical characteristics in 1099 patients with COVID-19 conducted by W. Guan and co-authors in China [11] describes the results regarding the smoking status of patients were provided for 1099 patients, of which 173 patients had a severe course of the disease, and 926 had a "non-severe" course. Among patients with severe symptoms, $16.9 \%$ were current smokers and 5.2\% were former smokers, in contrast to patients with non-serious symptoms, where $11.8 \%$ were current smokers and $1.3 \%$ were former smokers. In addition, in the group of patients who needed artificial ventilation of the lungs, were admitted to intensive care or died, $25.5 \%$ were current smokers and $7.6 \%$ were former smokers. In contrast, in the group of patients who did not have these adverse outcomes, only $11.8 \%$ were current smokers and $1.6 \%$ were former smokers [11].

In a study by Liu et al. out of 78 patients with COVID-19, the group with an adverse outcome had a significantly higher proportion of patients with a history of smoking $(27.3 \%)$ than the group that showed improvement or stabilization of the condition (3.0\%), with this difference being statistically significant at the level of $p=0.018$. In their multidimensional logistic regression analysis, smoking was identified as a risk 
factor for disease progression [18]. According to the results of a systematic review, even taking into account other factors that may affect the progression of the disease, smoking is most likely associated with negative progression and adverse outcomes of COVID-19 [25].

In Russian Federation, Super Job company conducted a survey on tobacco use during the period of self-isolation, which was attended by 1,600 people. According to the data obtained, $14 \%$ of respondents claim that they have become more likely to smoke in self-isolation. However, $26 \%$ of smokers noted a decrease in cigarette consumption. This may be due to a social factor and the lack of opportunities to go out for a smoke break with colleagues. More than half of the respondents (54\%) smoke normally. (Online media (radiokp.ru, 21.04.2020) https://www.who.int/news-room/qa-detail/q-a-on-smoking-and-COVID-19\#

Due to the fact that official state statistics on the spread of non-medical use of psychoactive substances during the COVID-19 pandemic in the Russian Federation and the Republic of Belarus at the time of preparation of this article (May, 2020) were not available, the assessment of the current drug situation was possible only on the basis of a study of the volume of sales of alcoholic beverages taken from open sources.

According to experts' estimates of the Russia's leading retailers, in March 2020, after the announcement of nonworking weeks and after a decrease in the hype demand for long-term storage goods, there was a weekly (March 9-15, March 16-22, March 23-29, 2020) growth in sales of alcoholic beverages:

- vodka by $10 \% ; 21 \% ; 31 \%$ (by week, respectively)

- whiskey at $19 ; 33 \% ; 47 \%$;

- beer by $15 \% ; 14 \% ; 25 \%$;

- sparkling wine by $11 \% ; 6 \% ; 5 \%$

Similarly, the Republic of Belarus recorded an increase in sales of alcoholic beverages in the first quarter of 2020 compared to the first quarter of 2019. Sales of cognac and cognac beverages, as well as low-alcohol beverages, especially strongly alcoholic beverages, has grown (according to the data of the National Statistical Committee of the Republic of Belarus) [20]:

- vodka at $103.3 \%$;

- cognac, cognac drinks and brandy at $126.1 \%$;

- beer at $106.6 \%$;

- low-alcohol beverages by $123.3 \%$;

- sparkling wines at $110.1 \%$;

- grape wines at $109.6 \%$;

- liquors at $109.7 \%$;

- fruit wines of $94.6 \%$.

The increase in retail alcohol sales in March 2020 was mainly due to non-clinical factors:
- Termination of on-line alcohol sales;

- The closure of cafes and restaurants;

- The fall in the ruble exchange rate and the population's fears about the rise in the price of alcohol;

- The deterioration of the epidemiological situation in Europe and the resulting public expectations of a shortage of alcohol supplied from there;

- Waiting for the "long weekend" by the population (in Russia);

- Lack of hand sanitizers and antiseptics and their replacement with strong alcoholic beverages.

Recommendations for the preservation of mental health and social well-being. The above features allow the development of rules for the preservation of mental health and social well-being.

First of all, it's information security. It is necessary to learn how to select reliable sources of information, check the facts and evaluate the reasonableness of the proposed conclusions. As a rule, reliable sources of information are those who are responsible for it. These are public media, newsletters of responsible international organizations (World Health Organization/WHO, UN), scientific publications, publications of relevant ministries and agencies. On the basis of the reliable information received, it is necessary to make conclusions about what to prepare for, what rules of conduct to observe, than to stock up, where to go.

The next level of protection is maintaining social partnerships at all levels (from rural communities and urban areas to megacities). At the individual level, one must never become self-contained, callous, far from the problems of others. It has been noticed since the First and Second World Wars that moral values, compassionate, empathetic skills and helping those who are worse off than you are helps to survive, stay human and stay healthy.

The third level of protection is measures aimed at preserving mental health at both the individual and population levels [27-29]. To reduce anxiety it is necessary to learn to be distracted, to "pass by ears" anxious thoughts, to switch to manual work, physical exercises. Planning the schedule of the day, daily recording of goals for the day helps to make life full, busy and struggling with boredom. If there are signs of anxiety or depression, do not hesitate to see a specialist: psychologist or psychotherapist. You should be very careful with alcohol consumption. People who have lost control over their drinks, and even more so, have started drinking, alcohol consumption is strictly prohibited, because "it will not end well. The phenomenon of "reducing the anti-suicidal barrier" against alcohol consumption is known [15]. Besides alcohol, one should beware of game and Internet addiction. Hang-up in computer games, strings, chats leads to mental 
exhaustion, increased anxiety when these chats are not available, insomnia, wasted time.

\section{Conclusions}

1. To date, the following factors have been identified as contributing to an increased risk of mental health impairment due to the COVID-19 pandemic:

- social isolation,

- loss of employment and lower income,

- inability to visit places that provide social support (temples, social centers, etc.),

- inability to provide full psychological and psychiatric care,

- psychosocial stress, world-wide anxiety over the constant news of the coronavirus in the media.

2. During the pandemic, many countries go through a period of so-called "self-isolation" or quarantine, during which people are forced for a long time not to see their loved ones, not to visit places of importance to them and experiencing constant anxiety and uncertainty due to changing living conditions. This has had a very negative impact on most people's mental state [30].

3. Analyzing data from many countries around the world, the World Health Organization (WHO) notes that the fear, loneliness, isolation, stress and anxiety experienced by all people during the COVID-19 pandemic can cause great mental health problems and countries need to be prepared for them. Depression, drug and alcohol addiction, self-harm and suicidal behavior are expected to increase [27], requiring increased preparedness by mental health services.

\section{References}

1. Coronavirus: shoppers stock up on alcohol amid lockdown. BBC World 2020. https://www.bbc.com/news/business-52226488

2. Calati R, Ferrari C, Brittner M, et al. Suicidal thoughts and behaviors and social isolation: a narrative review of the literature. J Affect Disord 2019;245:653-667.

https://doi.org/10.1016/j.jad.2018.11.022

3. Chandan JS, Taylor J, Bradbury-Jones C, et al. COVID-19: a public health approach to manage domestic violence is needed. The Lancet Public Health 2020;5(6).

https://doi.org/10.1016/S2468-2667(20)30112-2

4. COVID-19: stopping the rise in domestic violence during lockdown. 2020. https://www.europarl.europa.eu/news/en/ press-room/20200406IPR76610/covid-19-stopping-the-risein-domestic-violence-during-lockdown

5. deGoeij MC, Suhrcke M, Toffolutti V, et al. How economic crises affect alcohol consumption and alcohol-related health problems: a realist systematic review. Soc Sci Med 2015;131:131-46. https://doi.org/10.1016/j.socscimed.2015.02.025

6. Devries KM, Mak JY, Bacchus LJ, et.al. Intimate partner violence and incident depressive symptoms and suicide attempts: a systematic review of longitudinal studies. PLoS Med 2013; 10(5):e1001439.

https://doi.org/10.1371/journal.pmed.1001439

7. Evans SE, Davies C, DiLillo D. Exposure to domestic violence: a meta-analysis of child and adolescent outcomes. Aggression Violent Behavior 2008;13(2):131-140.

https://doi.org/10.1016/j.avb.2008.02.005

8. Gao J, Zheng P, Jia Y, et al. Mental health problems and social media exposure during COVID-19 outbreak. PLoS One 2020;15(4):e0231924.

https://doi.org/10.1371/journal.pone.0231924

9. Garfin DR. The novel coronavirus (COVID-19) outbreak: amplification of public health consequences by media exposure. Health Psychology 2020;39(5):355. https://doi.org/10.1037/hea0000875

10. Golding JM. Intimate partner violence as a risk factor for mental disorders: a meta-Analysis. J Fam Viol 1999;14(2):99-132. https://doi.org/10.1023/A:1022079418229

11. Guan W, Ni Z, Hu Y, et al. Clinical characteristics of coronavirus disease 2019 in China. New Engl J Med 2020.

12. Hawkley LC, Cacioppo JT. Loneliness matters: a theoretical and empirical review of consequences and mechanisms. Ann Behav Med 2010;40(2):218-27. https://doi.org/10.1007/s12160-010-9210-8

13. Kawohl W, Nordt C. COVID-19, unemployment, and suicide. Lancet Psychiatry 2020;7(5):389-390. https://doi.org/10.1016/S2215-0366(20)30141-3

14. Keyes KM, Hatzenbuehler ML, Hasin DS. Stressful life experiences, alcohol consumption, and alcohol use disorders: the epidemiologic evidence for four main types of stressors. Psychopharmacology (Berl) 2011;218(1):1-17. https://doi.org/10.1007/s00213-011-2236-1

15. Kondrashenko VT, Igumnov SA. Deviant behavior in teenagers: diagnostics, prevention, correction. Minsk: AVERSEV 2004;367.

16. Lapanov PS, Salivonchik DP, Igumnov SA, et al. Method for estimation of sensitivity of cardiovascular system to intensive single psycho-emotional influences (in Russian): instruction // Ministry of Health of the Republic of Belarus, April 25, 2019, Reg. № 036-0419. Min Health Rep Belar 2019;14.

17. Leigh-Hunt N, Bagguley D, Bash K, et al. An overview of systematic reviews on the public health consequences of social isolation and loneliness. Publ Health. 2017;152:157-171. https://doi.org/10.1016/j.puhe.2017.07.035

18. Liu W, Tao ZW, Lei W, et al. Analysis of factors associated with disease outcomes in hospitalised patients with 2019 novel coronavirus disease. Chin Med J 2020;133(9):1032-1038. https://doi.org/10.1097/CM9.0000000000000775 
19. Nagelhout GE, Hummel K, de Goeij MCM, de Vries H, Kaner E, Lemmens P. How economic recessions and unemployment affect illegal drug use: a systematic realist literature review. Int J Drug Policy 2017;44:69-83.

https://doi.org/10.1016/j.drugpo.2017.03.013

20. Sales of certain food products by trade organizations of the Republic of Belarus in the first quarter of 2020 // Nation Statist Comm Rep Belar. https://www.belstat.gov.by/ofitsialnayastatistika/realny-sector-ekonomiki/vnytrennia-torgovlya/ roznichnaya-torgovlya/operativnye-dannye_13/

21. Soole R, Kõlves K, Leo DD. Suicide in children: a systematic review. 2015. http://dxdoiorgproxykibkise/101080/138111182014996694.

22. Sprang G, Silman M. Posttraumatic stress disorder in parents and youth after health-related disasters. Disaster Med Public Health Prep 2013;7(1):105-10. https://doi.org/10.1017/dmp.2013.22

23. Pandemic school closures: risks and opportunities. Lancet Child Adolesc Health 2020;4(5):341. https://doi.org/10.1016/S2352-4642(20)30105-X

24. Van Lancker W, Parolin Z. COVID-19, school closures, and child poverty: a social crisis in the making. Lancet Public Health 2020;5(5):e243-e244. https://doi.org/10.1016/S2468-2667(20)30084-0

25. Vardavas CI, Nikitara K. COVID-19 and smoking: a systematic review of the evidence. Tob Induc Dis 2020;18:20. https://doi.org/10.18332/tid/119324

26. Wasserman D, van der Gaag R, Wise J. Terms 'physical distancing' and 'emotional closeness' should be used and not 'social distancing' when defeating the COVID-19 pandemic.Science 2020;367(6484):1282-1282. org/content/367/6484/1282/tab-e-letters https://doi.org/10.1126/science.abb7518

27. Mental health and psychosocial considerations during the COVID-19 outbreak. WHO 2020. https://www.who.int/docs/ default-source/coronaviruse/mental-health-considerations. pdf?sfvrsn $=6 \mathrm{~d} 3578$ af_10
28. Coronavirus disease (COVID-19) pandemic. WHO 2020.

https:/www.who.int/emergencies/diseases/novel-coronavirus-2019

29. Preventing suicide: a global imperative. WHO 2014:92.

30. Zagorski N. Experts warn efforts to contain COVID-19 may increase risk of suicide. Psychiatric News 2020;55(10). https://doi.org/10.1176/appi.pn.2020.5b19

31. Zatti C, Rosa V, Barros A, et al. Childhood trauma and suicide attempt: a meta-analysis of longitudinal studies from the last decade. Psychiatry Res 2017;256:353-358.

https://doi.org/10.1016/j.psychres.2017.06.082

\section{PSICHOLOGINIAI RIZIKOS VEIKSNIAI PSICHIKOS SVEIKATAI PANDEMIJOS METU S. Igumnov}

Raktažodžiai: nerimas, COVID-19, pandemija, psichoaktyviosios medžiagos, karantinas, saviizoliacija, stresas.

Santrauka

Pandemijos metu daugelis šaliu patyrè saviizoliacijos arba karantino periodą, kurio metu žmonès buvo priversti ilgą laiką nesimatyti su artimaisiais, nesilankyti jiems svarbiose vietose ir išgyveno pastovų nerimą bei neužtikrintumą dèl pasikeitusių gyvenimo sąlygų. Tai labai stipriai neigiamai paveikė daugelio žmonių psichikos sveikatą. Pasaulio sveikatos organizacija, analizuodama duomenis iš įvairių pasaulio šalių, pabrèžè, kad baimè, vienišumas, izoliacija, stresas ir nerimas, patirti daugelio žmonių COVID-19 pandemijos metu, gali sukelti reikšmingas psichikos sveikatos problemas, todèl šalys turi būti tam pasirengusios. Depresija, piktnaudžiavimas alkoholiu ir narkotinèmis medžiagomis bei priklausomybė nuo jų, savižala ir suicidinis elgesys tikètinai gali išaugti, todèl būtina, kad psichikos sveikatos priežiūros tarnybos būtų tam pasirengusios.

Adresas susirašinèti: sigumnov67@gmail.com

Gauta 2020-06-17 